\title{
Arsenic trioxide inhibits glioma cell growth through induction of telomerase displacement and telomere dysfunction
}

\author{
Ye Cheng ${ }^{1}$, Yunqian $\mathrm{Li}^{1}$, Chengyuan $\mathrm{Ma}^{1}$, Yang Song ${ }^{1}$, Haiyang $\mathrm{Xu}^{1}$, Hongquan $\mathrm{Yu}^{1}$, \\ Songbai Xu' ${ }^{1}$, Qingchun $\mathrm{Mu}^{1}$, Haisong $\mathrm{Li}^{1}$, Yong Chen ${ }^{1}$, Gang Zhao ${ }^{1}$ \\ ${ }^{1}$ Department of Neurosurgery, First Hospital of Jilin University, Changchun, P. R. China \\ Correspondence to: Yong Chen, e-mail: cy_9201982@aliyun.com \\ Gang Zhao, e-mail: zhaogang_jdyy@163.com
}

Keywords: $\mathrm{As}_{2} \mathrm{O}_{3}$, telomere, telomerase, glioma, growth inhibition

Received: October 20, $2015 \quad$ Accepted: January 24, 2016

Published: February 8, 2016

\begin{abstract}
Glioblastomas are resistant to many kinds of treatment, including chemotherapy, radiation and other adjuvant therapies. $\mathrm{As}_{2} \mathrm{O}_{3}$ reportedly induces $\mathrm{ROS}$ generation in cells, suggesting it may be able to induce telomerase suppression and telomere dysfunction in glioblastoma cells. We show here that $\mathrm{As}_{2} \mathrm{O}_{3}$ induces ROS generation as well as telomerase phosphorylation in U87, U251, SHG4 and C6 glioma cells. It also induces translocation of telomerase from the nucleus to the cytoplasm, thereby decreasing total telomerase activity. These effects of $\mathrm{As}_{2} \mathrm{O}_{3}$ trigger an extensive DNA damage response at the telomere, which includes up-regulation of ATM, ATR, 53BP1, $\gamma-\mathrm{H}_{2} \mathrm{AX}$ and Mer11, in parallel with telomere fusion and $3^{\prime}$-overhang degradation. This ultimately results in induction of p53- and p21-mediated cell apoptosis, G2/M cell cycle arrest and cellular senescence. These results provide new insight into the antitumor effects of $\mathrm{As}_{2} \mathrm{O}_{3}$ and can perhaps contribute to solving the problem of glioblastoma treatment resistance.
\end{abstract}

\section{INTRODUCTION}

Glioblastoma is one of the most common and devastating primary malignant intracranial tumors occurring in humans. The current therapy for newly diagnosed glioblastoma is surgical resection followed by radiotherapy plus chemotherapy [1]. However, the prognosis is poor, with a median overall survival of only 14.6 months, a median progression-free survival of 6.9 months, and a 5-year survival rate of only $9.8 \%$ after diagnosis $[1,2]$. Malignant gliomas are resistant to many kinds of treatment, including chemotherapy, radiation and other adjuvant therapies. Moreover, glioma cells are prone to acquiring drug resistance systems. Consequently, there is a need to identify chemotherapeutic agents with cytotoxicity toward glioma cells [3].

Arsenic trioxide $\left(\mathrm{As}_{2} \mathrm{O}_{3}\right)$ is a naturally occurring arsenic compound traditionally regarded as poisonous [4], though it has been used as a therapeutic agent since 15 th century. In $1970 \mathrm{~s}, \mathrm{As}_{2} \mathrm{O}_{3}$ was found to be effective in the treatment of acute promyelocytic leukemia (APL) [5, $6]$, and has been tested in clinical trials of APL patients worldwide since then. There are now studies reporting the cytotoxic potential of $\mathrm{As}_{2} \mathrm{O}_{3}$ in many malignant tumors, including breast and lung cancers [7, 8]. In the 2000s, $\mathrm{As}_{2} \mathrm{O}_{3}$ was reported to inhibit growth of malignant glioma cell lines and to induce cell death. Moreover, anticancer therapy using $\mathrm{As}_{2} \mathrm{O}_{3}$ has been shown to be safe and effective in both the short-term and long-term [9].

The mechanism by which $\mathrm{As}_{2} \mathrm{O}_{3}$ induces cell death is not fully understood. The compound reportedly induces DNA and chromosomal damage, inhibits DNA repair, and alters DNA methylation in mammalian cells [10]. Phatak [11] reported that telomere erosion and reduced telomerase activity is the main cause of $\mathrm{As}_{2} \mathrm{O}_{3}$-induced cell toxicity. Although it is not universal, elevated telomerase activity is frequently detected in advanced cancer cells and is important for continuous cancer cell proliferation $[12,13$, 14]. In glioblastoma cells, for example, over-expressed telomerase stabilizes telomeres [15]. However, there is as yet no evidence that the anti-proliferative effect $\mathrm{As}_{2} \mathrm{O}_{3}$ on glioblastoma cells reflects interference with telomeres or telomerase activity. Our aim in the present study was to determine the mechanism by which $\mathrm{As}_{2} \mathrm{O}_{3}$ might 
inhibit telomerase activity and the site of any induced DNA damage. We also sought to shed light on the effect of $\mathrm{As}_{2} \mathrm{O}_{3}$ to cell apoptosis, cell cycle arrest and cellular senescence.

\section{RESULTS}

\section{$\mathrm{As}_{2} \mathrm{O}_{3}$ is cytotoxic and induces ROS generation in glioma cells and inhibits cell migration and invasion}

We examined effect of $\mathrm{As}_{2} \mathrm{O}_{3}$ on the proliferation of U87, U251, SHG44 and C6 cells using MTT assays at clinically achievable $\mathrm{As}_{2} \mathrm{O}_{3}$ concentrations [3]. Obvious dose-and time-dependent inhibition of growth was observed in all four cell types (Figure 1A). Following exposure with $\mathrm{As}_{2} \mathrm{O}_{3}$ for $48 \mathrm{~h}$, the $50 \%$ inhibition of growth concentrations (IC50s) were 4.45 $\mu \mathrm{M}$ in $\mathrm{U} 87,4.67 \mu \mathrm{M}$ in $\mathrm{U} 251,4.98 \mu \mathrm{M}$ in SHG44 and $5.56 \mu \mathrm{M}$ in C6 cells. In all four cell types, we observed a stronger inhibitory effect at $48 \mathrm{~h}$ than $24 \mathrm{~h}$, and the inhibitory effect was stronger at $72 \mathrm{~h}$ than $48 \mathrm{~h}$ with higher $\mathrm{As}_{2} \mathrm{O}_{3}$ concentrations $(8 \mu \mathrm{M}$ and $16 \mu \mathrm{M})$. These results are similar to those of $\mathrm{Wu}[16]$, who studied the time-dependent effect of $\mathrm{As}_{2} \mathrm{O}_{3}$ on U87 and U251 cell viability. Our study also indicates that after $48 \mathrm{~h}$ of treatment, the inhibitory effects significantly differ between $2 \mu \mathrm{M}$ and $16 \mu \mathrm{M} \mathrm{As}_{2} \mathrm{O}_{3}$ which is similar to the finding of Wang [17], who studied the dose-dependent effect of $\mathrm{As}_{2} \mathrm{O}_{3}$ in U87 cells. We extended those findings by adding the study of SHG44 (another type of malignant human glioma) and C6 (mouse glioma cells) cell. Our results indicate the inhibitory effect of $\mathrm{As}_{2} \mathrm{O}_{3}$ is significantly weaker in C6 cells (Figure 1B), which may reflect its lower malignancy as compared to U87 and U251 cells [18]. Furthermore, we found that $\mathrm{As}_{2} \mathrm{O}_{3}$ induces dose-dependent generation of ROS in U87, U251 and SHG44 cells (Figure 1C). After $48 \mathrm{~h}$ of $\mathrm{As}_{2} \mathrm{O}_{3}$ treatment, the ROS generation was higher in U87 than C6 cells (Figure 1D). In addition, $\mathrm{As}_{2} \mathrm{O}_{3}$ significantly and dose-dependently reduced migration and invasion by U87, U251 and SHG44 cells (Figure 1E, 1F).

\section{$\mathrm{As}_{2} \mathrm{O}_{3}$ inhibits telomerase displacement, phosphorylation and activity}

Telomerase displacement from the nucleus to the cytoplasm was examined using both immunofluorescence and immunoblotting. Immunofluorescence indicated that after treatment with $4 \mu \mathrm{M} \mathrm{As} \mathrm{O}_{3}$ for $48 \mathrm{~h}$, there was significant cytoplasmic accumulation of telomerase catalytic subunit (hTERT), and this effect could be inhibited by NAC, a ROS scavenger (Figure 2A, 2B). This finding was confirmed by immunoblotting hTERT in both nuclear and cytosolic extract (Figure 2C, 2D).
Furthermore, we found that displacement of hTERT is also dose-dependent, which is consistent with the level of ROS generation.

The detection of phosphorylated hTERT suggested that $\mathrm{As}_{2} \mathrm{O}_{3}$ induces Tyr707 phosphorylation of telomerase (Figure 2C). To assess the effect of $\mathrm{As}_{2} \mathrm{O}_{3}$ on telomerase enzymatic activity, we performed telomeric repeat amplification protocol (TRAP) assays with telomerase extracts from U87, U251, SHG44 and C6 cells. Activity levels were then determined through gray scale analysis. We found that $\mathrm{As}_{2} \mathrm{O}_{3}$ inducedsignificant dose- and time-dependent inhibition of telomerase activity in all four cell types, though the inhibitory effects differed significantly between U87 and C6 cells (Figure 2D, 2E and Sup Figure S1).

\section{$\mathrm{As}_{2} \mathrm{O}_{3}$ induces DNA damage and telomere instability}

Telomerase inhibition leads to DNA damage and telomere dysfunction. Using immunofluorescence and immunoblotting, we detected DNA damage-related proteins after treatment with $\mathrm{As}_{2} \mathrm{O}_{3}$ in U87 cells. Immunofluorescent labeling showed that ATR, 53BP1, $\gamma-\mathrm{H}_{2} \mathrm{AX}$ and Mer11 accumulated in the nucleus of cells exposed to $4 \mu \mathrm{M} \mathrm{As}_{2} \mathrm{O}_{3}$ for $48 \mathrm{~h}$ (Figure $3 \mathrm{~A}$ ). In addition, obvious dose-related increases in p-ATM, ATR, $\gamma$ - $\mathrm{H}_{2} \mathrm{AX}$, 53BP1, Mer11, and $\mathrm{p} 21$ were detected by immunoblotting (Figure 3B). This indicates a strong and complex effect of DNA damage induced by $\mathrm{As}_{2} \mathrm{O}_{3}$. Telomere fusion was found after exposure to $\mathrm{As}_{2} \mathrm{O}_{3}$ (Figure 3C). We also used hybridization protection assays (HPA) to investigate the effect of $\mathrm{As}_{2} \mathrm{O}_{3}$ on telomeric G-overhang length and the total telomere length. As shown in (Figure 3D), $\mathrm{As}_{2} \mathrm{O}_{3}$ significantly reduced the telomeric G-overhang length after $48 \mathrm{~h}$ of treatment $(\mathrm{P}<0.01)$, though the total telomere length did not change.

\section{DNA-damage response triggered by $\mathrm{As}_{2} \mathrm{O}_{3}$ occurred at the telomere}

To verify whether ATR, $\gamma$ - $\mathrm{H}_{2} \mathrm{AX}, 53 \mathrm{BP} 1$, and Mer11 were activated at telomeres, double immunofluorescence experiments were performed using U87 cells. Confocal microscopy revealed that most ATR, $\gamma-\mathrm{H}_{2} \mathrm{AX}, 53 \mathrm{BP} 1$ and Mer11 foci induced by $\mathrm{As}_{2} \mathrm{O}_{3}$ co-localized with TRF1 (Figure 4A-4D), forming so-called telomere dysfunctioninduced foci (TIFs) [19]. Quantitative analysis indicated that $\mathrm{As}_{2} \mathrm{O}_{3}$ significantly increased the percentage of cells with more than four ATR/TRF1, $\gamma-\mathrm{H}_{2} \mathrm{AX} / \mathrm{TRF} 1,53 \mathrm{BP} 1 /$ TRF1 and Mer11/TRF1 co-localizations (the percentage of TIF-positive cells reached about $65 \%$ after treatment; $\mathrm{P}<0.01$ ), with a mean of about eight TIFs per nucleus (Figure 4E-4F). ChIP assays confirmed that $\gamma-\mathrm{H}_{2} \mathrm{AX}$ and 53BP1 associated with telomeres in $\mathrm{As}_{2} \mathrm{O}_{3}$-treated cells (Figure 4G) $[12,13,20]$. 


\section{$\mathrm{As}_{2} \mathrm{O}_{3}$ evokes cell apoptosis, cell cycle arrest and cellular senescence}

We also explored whether $\mathrm{As}_{2} \mathrm{O}_{3}$-induced DNA damage in telomeres led to apoptosis, cell cycle arrest or cellular senescence. We first tested the effect of $\mathrm{As}_{2} \mathrm{O}_{3}$ on the incidence of apoptosis by staining cells with Annexin $\mathrm{V}$ and PI. As that the proportion of apoptotic cells in the lower right quadrant was increased in a dose-dependent manner (Figure 5A-5B), which is in agreement with
A
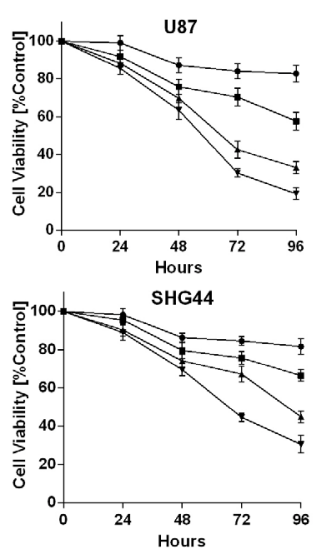

C
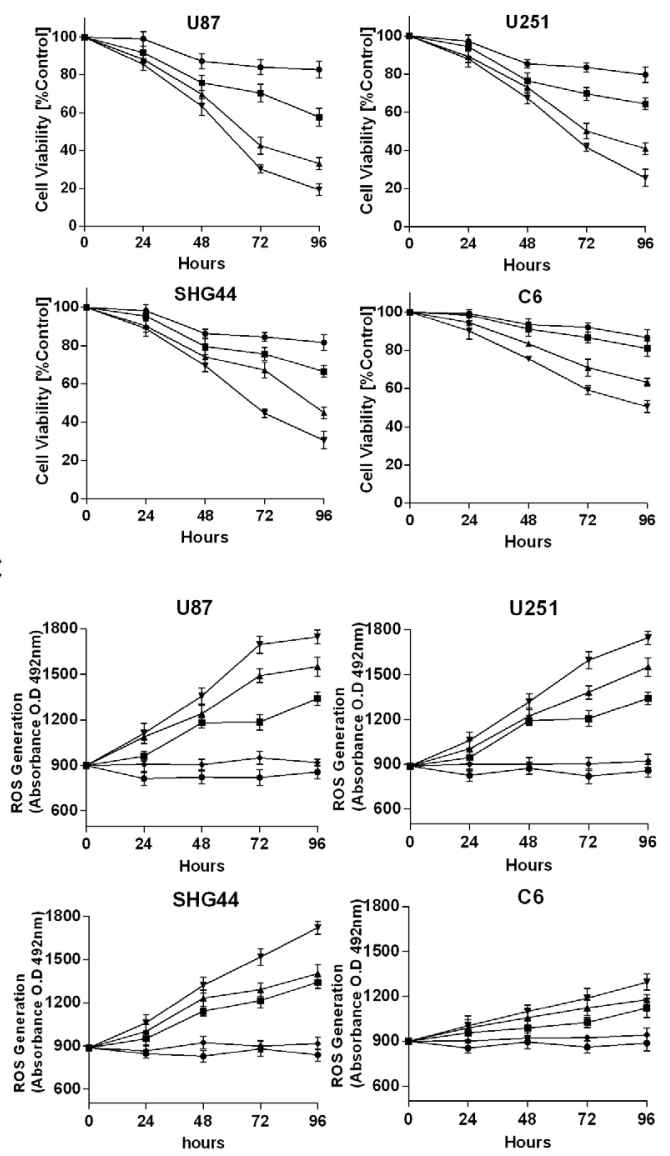

E
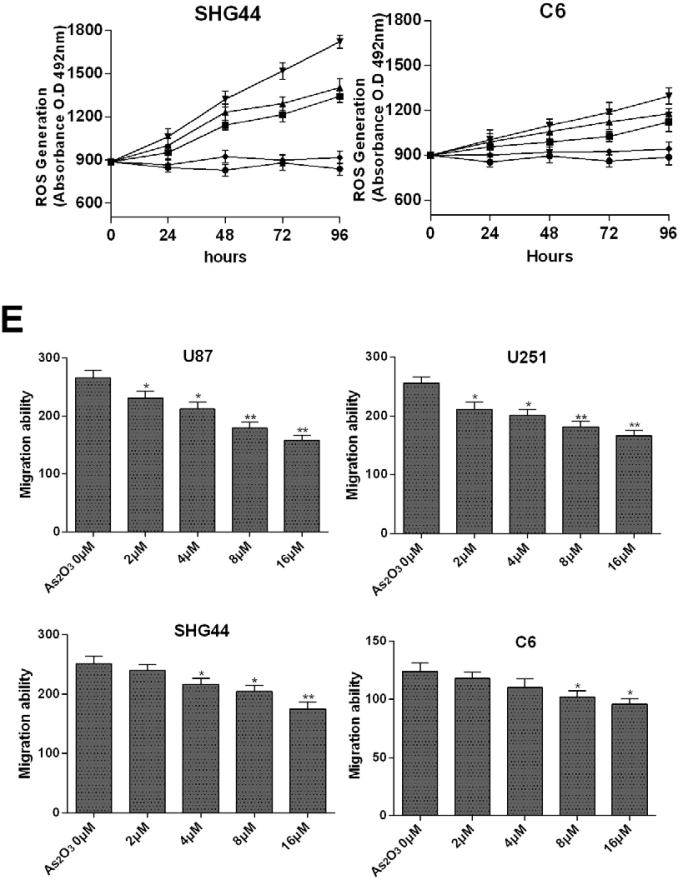

B

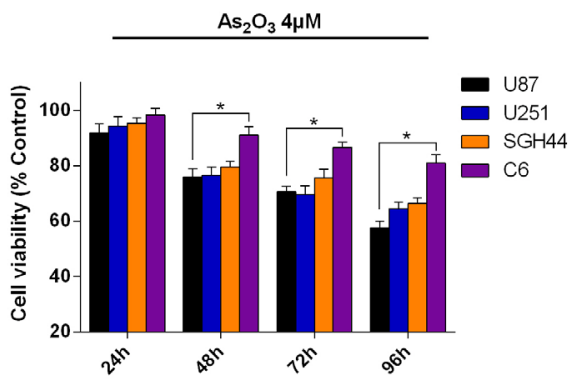

D

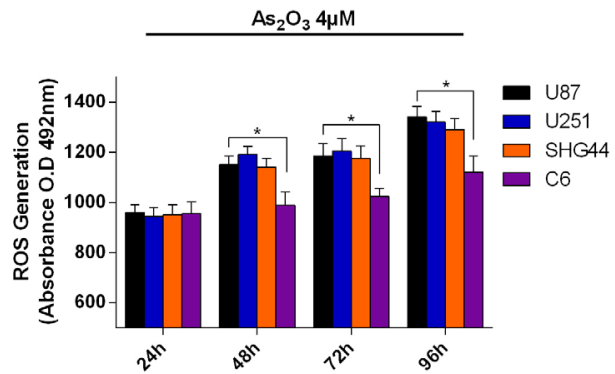

$\mathbf{F}$
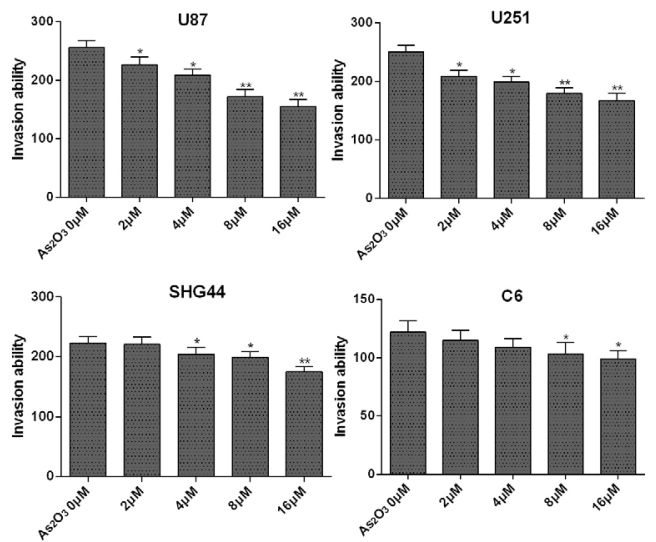

Figure 1: Growth suppression and ROS generation induced by $\mathrm{As}_{2} \mathrm{O}_{3}$ in glioma cells. A. MTT analysis of cell viability in U87, U251, SHG44 and C6 cell lines after exposure to $\mathrm{As}_{2} \mathrm{O}_{3}$ at $2(\bullet), 4(\boldsymbol{\bullet}), 8(\mathbf{\Delta})$ or $16 \mu \mathrm{M}(\boldsymbol{\nabla})$ for 24, 48, 72 and $96 \mathrm{~h}$. B. Comparison of the viability of the indicated cells after exposure to $4 \mu \mathrm{M} \mathrm{As}_{2} \mathrm{O}_{3}$ for 24, 48, 72 and 96 h. C. ROS generation in the indicated cell lines induced by $\mathrm{As}_{2} \mathrm{O}_{3}$ at $0(\bullet), 2(\bullet), 4(\boldsymbol{\bullet}), 8(\boldsymbol{\Delta})$ and $16 \mu \mathrm{M}(\boldsymbol{\nabla})$. ROS were detected based on O.D. $492 \mathrm{~nm}$ measured using a microplate reader. D. Comparison ofROS generation in the indicate cell types after exposure to $4 \mu \mathrm{M} \mathrm{As}_{2} \mathrm{O}_{3}$ for 24, 48, 72 and $96 \mathrm{~h}$. E. $\mathrm{As}_{2} \mathrm{O}_{3}$ inhibits migration of glioma cells in vitro. Migration by the indicated cell types was inhibited by pretreatment with 0-16 $\mu \mathrm{M} \mathrm{As}_{2} \mathrm{O}_{3}$. F. $\mathrm{As}_{2} \mathrm{O}_{3}$ inhibits invasion by glioma cells in vitro. Error bars indicate s.d. ${ }^{* *} \mathrm{P}<0.05,{ }^{*} \mathrm{P}<0.01$, two-tailed Student's $t$-test. 
A

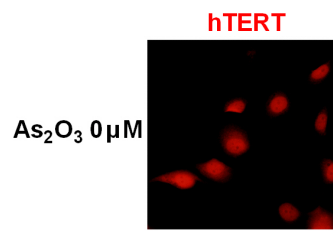

hTERT

$4 \mu \mathrm{M}$

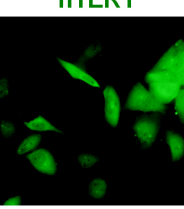

hTERT

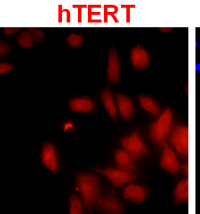

C
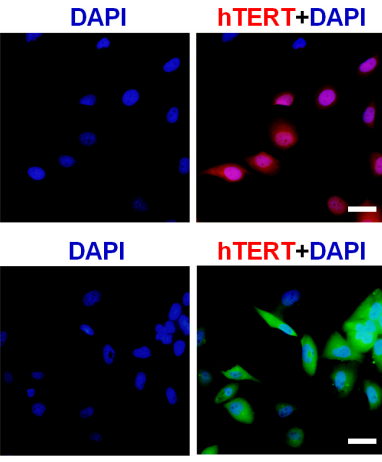

hTERT+DAPI

$4 \mu \mathrm{M}+\mathrm{NA}$

DAPI

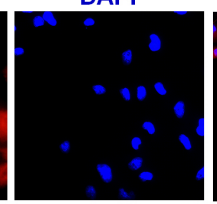

hTERT+DAPI
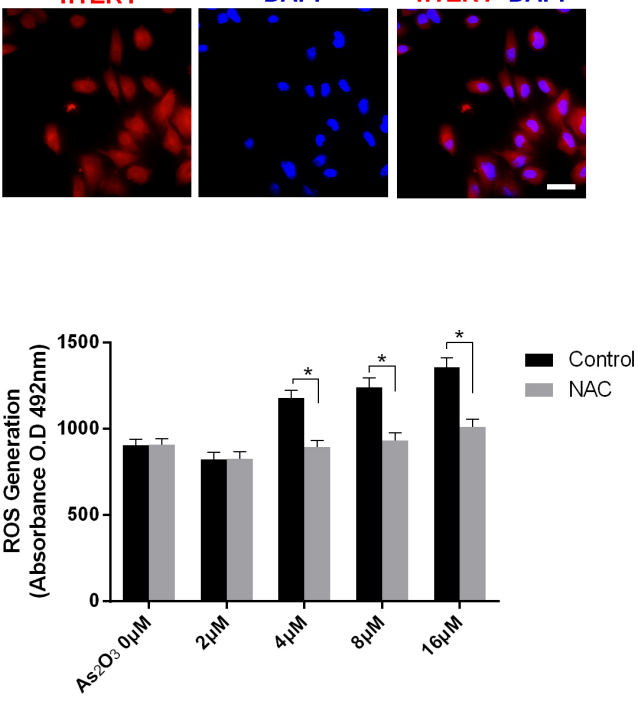

D

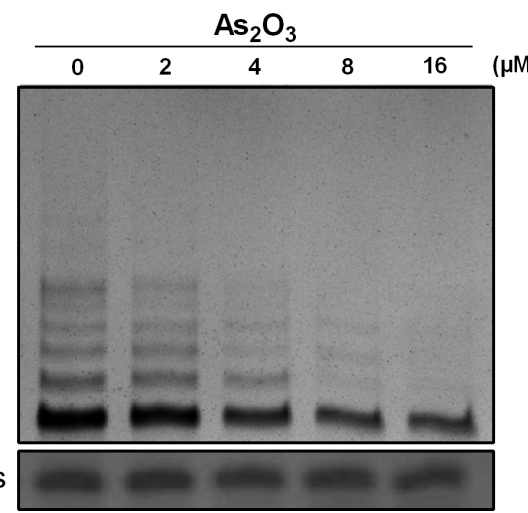

B
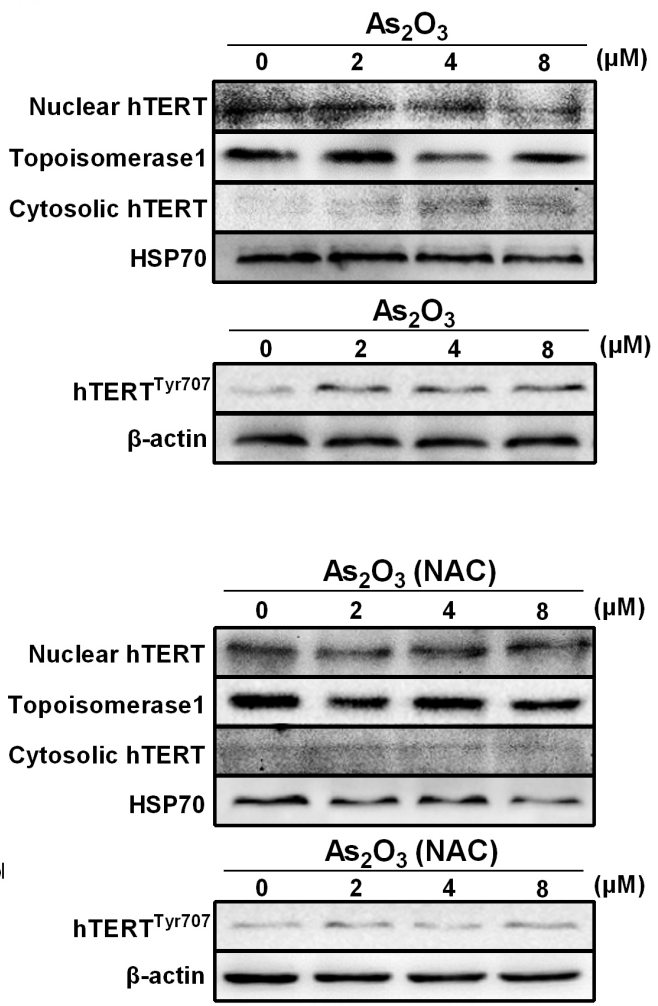

E

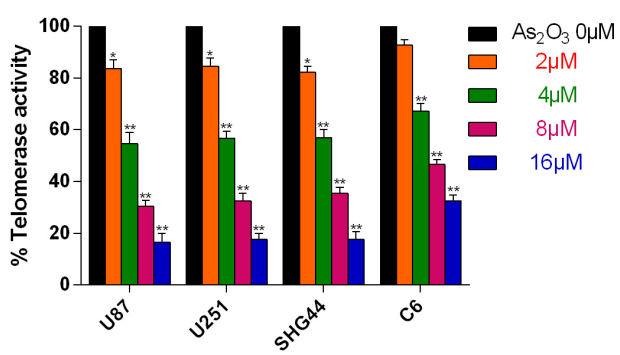

Figure 2: $\mathrm{As}_{2} \mathrm{O}_{3}$ inhibits telomerase translocation, phosphorylation and activity. A. Immunofluorescent detection of the telomerase catalytic subunit (hTERT) in control U87 cells (green) and cells exposed to $4 \mu \mathrm{M} \mathrm{As}_{2} \mathrm{O}_{3}$ (green) or $4 \mu \mathrm{M} \mathrm{As} \mathrm{O}_{3}$ plus NAC (red). The translocation of hTERT from the nucleus to the cytoplasm was evidenced from the difference in hTERT accumulation. Cells were pretreated with NAC $(1 \mathrm{mM})$ before $\mathrm{As}_{2} \mathrm{O}_{3}$ treatment. Scale bar $=25 \mu \mathrm{m}$. B. ROS generation induced by $0-16 \mu \mathrm{M} \mathrm{As}_{2} \mathrm{O}_{3}$ with and without NAC. ${ }^{*} \mathrm{P}<0.05,{ }^{* *} \mathrm{P}<0.01$. C. Immunoblots showing the presence of hTERT in both nuclear and cytosolic extracts from cells exposed to $0-8 \mu \mathrm{M} \mathrm{As} \mathrm{O}_{3}$. The level of hTERT protein in the nucleus decreased as the cytoplasmic level increased. HSP70 was used as an internal standard for the cytoplasm, and topoisomerase 1 was used as an internal standard for the nucleus. The expression of hTERT Tyr707 indicated the phosphorylation of telomerase. D. $\mathrm{As}_{2} \mathrm{O}_{3}$-induced inhibition of telomerase activity in $\mathrm{U} 87$ cells. TRAP assays performed after $48 \mathrm{~h}$ of $\mathrm{As}_{2} \mathrm{O}_{3}$ treatment show dose-dependent inhibition of telomerase activity. The position of the internal standard was indicated as IS. E. Dosedependent inhibition of telomerase activity in U87, U251, SHG44 and C6 cells. ${ }^{*} \mathrm{P}<0.05,{ }^{*} \mathrm{P}<0.01$ as compared with controls. 
the findings by others, who showed that $\mathrm{As}_{2} \mathrm{O}_{3}$ has the potential to induce apoptotic cell death [21]. Moreover, immunoblotting revealed dose- and time-dependent upregulation of the pro-apoptotic proteins p53, p-p53 and Bax and down-regulation of anti-apoptotic protein Bcl2 in U87 cells. We also observed elevation of PARP and Caspase-3 cleavage, which is consistent with increased incidence of apoptosis (Figure 5C). Collectively, these data suggest that glioma cells exposed to $\mathrm{As}_{2} \mathrm{O}_{3}$ in the short term undergo p53- and caspase-based apoptosis. This result is in agreement with that of Qian [22].

We next analyzed the percentages of cells in the different phases of the cell cycle. As shown in Figure 5D$5 \mathrm{E}$, most of the cells in the control group are in G0-G1 phase. By contrast, $\mathrm{As}_{2} \mathrm{O}_{3}$ induced $\mathrm{G} 2-\mathrm{M}$ phase arrest, which is in agreement with the reported effect of $\mathrm{As}_{2} \mathrm{O}_{3}$ on Burkitt's lymphoma cells [23]. To provide additional evidence to support the $\mathrm{As}_{2} \mathrm{O}_{3}$-induced $\mathrm{G} 2-\mathrm{M}$ phase arrest, we used immunoblotting to detect expression of Cyclin B1, Cyclin D1, Aurora A and phospho-Aurora A. We found that $\mathrm{As}_{2} \mathrm{O}_{3}$ treatment led to a dose-dependent decrease of Cyclin B1, Aurora A and phospho-Aurora A, which is indicative of failure of $\mathrm{G} 2$ to $\mathrm{M}$ phase transition $[24,25]$. On the other hand, the lack of change in Cyclin D1 indicates no obstruction in G1 to S transition (Figure 5F) [26].

Using aging staining we also observed that $\mathrm{As}_{2} \mathrm{O}_{3}$ treatment for 2 weeks increased the incidence of cellular senescence marked by cell swelling and blue staining. Dose-related effects were seen with all of four cell types tested (Figure 5G, 5H).

\section{DISCUSSION}

Telomeres are specialized DNA structures located at the ends of chromosomes and are progressively shortened during each cell division [27]. Telomerase enables cells to escape this proliferation barrier by stabilizing telomeres [28]. It has been reported that telomerase, and specifically its catalytic subunit hTERT, is overactive in $85-90 \%$ of cancers (including glioblastomas), and it has become a widely accepted tumor marker and a popular target for anticancer therapeutics [29-30]. Telomerase inhibition can therefore be used as a therapeutic strategy

B

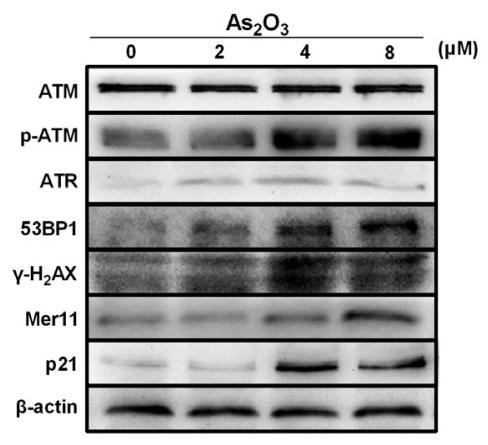

D

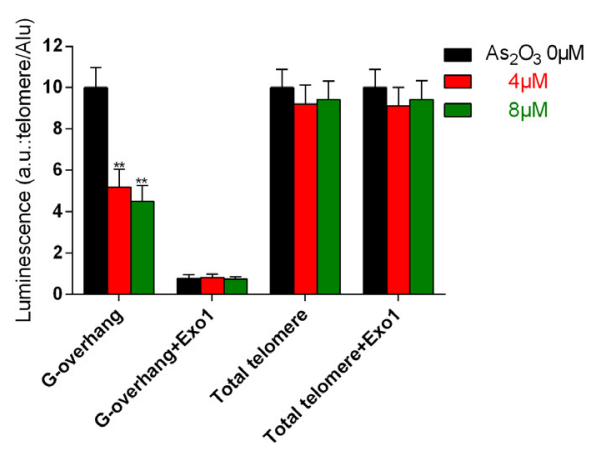

Figure 3: $\mathrm{As}_{2} \mathrm{O}_{3}$-induced DNA damage and chromosome instability is associated with degradation of telomeric G-overhang. A. Representative immunofluorescence images of ATR, 53BP1, $\gamma-\mathrm{H}_{2} \mathrm{AX}$ and Mer11 foci in U87 cells treated with $4 \mu \mathrm{M}$ $\mathrm{As}_{2} \mathrm{O}_{3}$ for $48 \mathrm{~h}$. Scale bar $=15 \mu \mathrm{m}$. B. Immunoblots showing up-regulation of p-ATM, ATR, 53BP1, $\gamma$ - $\mathrm{H}_{2} \mathrm{AX}$, p21 and Mer11 proteins in U87 cells treated for $48 \mathrm{~h}$ with $4 \mu \mathrm{M} \mathrm{As}_{2} \mathrm{O}_{3}$. Immunoblotting $\beta$-actin confirmed equivalent protein loading. Each experiment was repeated three times. C. Telomere fusion induced by treatment with $4 \mu \mathrm{M} \mathrm{As}_{2} \mathrm{O}_{3}$ for $48 \mathrm{~h}$. Chromosomes were stained with Giemsa. Scale bar $=5$ $\mu \mathrm{m}$. D. Hybridization protection assays (HPAs) were performed on genomic DNA isolated from glioma cells treated with As $\mathrm{O}_{3}$ to assess G-overhang length and total telomere length. Exo 1 nuclease digestion was used to assess integrity of the 3'-overhang. Luminescence intensity in arbitrary units (AU) was normalized against Alu probe. The mean of three independent experiments with comparable results is shown. Error bars indicate \pm s.d., $* * \mathrm{P}<0.01$, two-tailed Student's $t$-test. 
for selectively targeting malignant gliomas. Usually, telomerase inhibition is accomplished through mRNA interference, expression control, phosphorylation of hTERT, or assembly and export from the nucleus [31]. Multiple kinase and phosphatase activators and inhibitors affect telomerase phosphorylation status and in turn its structure, localization and enzyme activity [32, 33]. In our study, we first found that $\mathrm{As}_{2} \mathrm{O}_{3}$-induced telomerase phosphorylation led to its translocation from the nucleus to the cytoplasm. Dose- and time-dependent ROS generation appears to be the main cause of hTERT phosphorylation and displacement [34]. The phosphorylation and displacement of hTERT disrupted the subunit's ability to catalyze repair of the telomere, which would lead to telomere dysfunction [35].

Telomere dysfunction can also be the result of DNA damage. DNA damage can be related to cell activities, such as malignant transformation and cell death [36].
It was recently reported that ROS is an important cause of DNA damage [37]. Thus as a ROS generator, $\mathrm{As}_{2} \mathrm{O}_{3}$ has the ability to induce DNA damage. However, the site(s) at which damage occurs and the mechanism remains unclear. Our study indicated that DNA damage induced by $\mathrm{As}_{2} \mathrm{O}_{3}$ reflects the activation of ATM and its downstream effects. The increase of phospho-ATM and ATR indicates the induction of DNA double-strand breaks as well as replication fork arrest [38]. The double-strand breaks promote expression of ATM, while replication fork blockage promotes ATR expression [39]. The increase in $\mathrm{H}_{2} \mathrm{AX}$, which is induced by phospho-ATM and ATR, is part of the downstream DNA damage response. The upregulation of $53 \mathrm{BP} 1$, which is also indicative of DNA double-streand breaks, is caused by the activation of ATM and ATR [40]. The up-regulation of Mer11 is another downstream effector of ATM and ATR induced in response to DNA damage. Notably, we found that ATR, 53BP1,
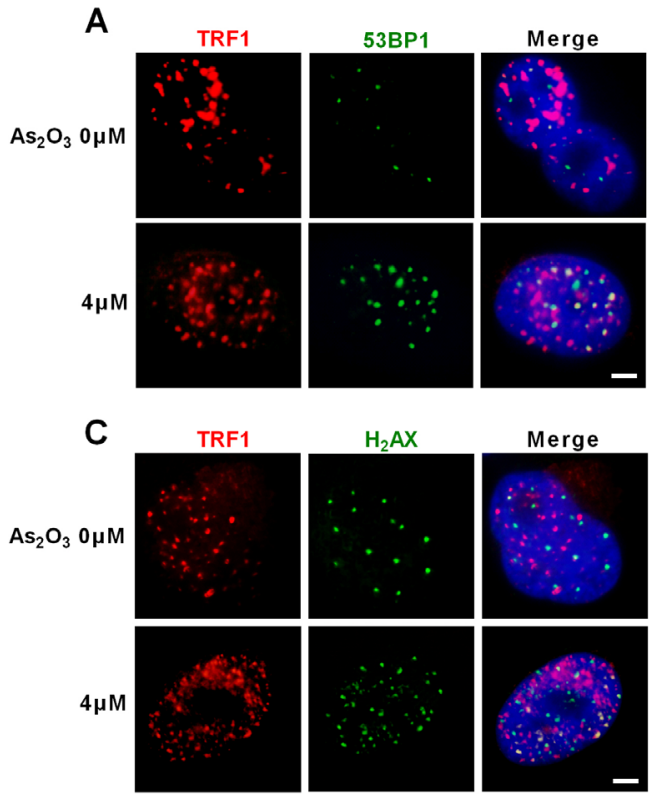
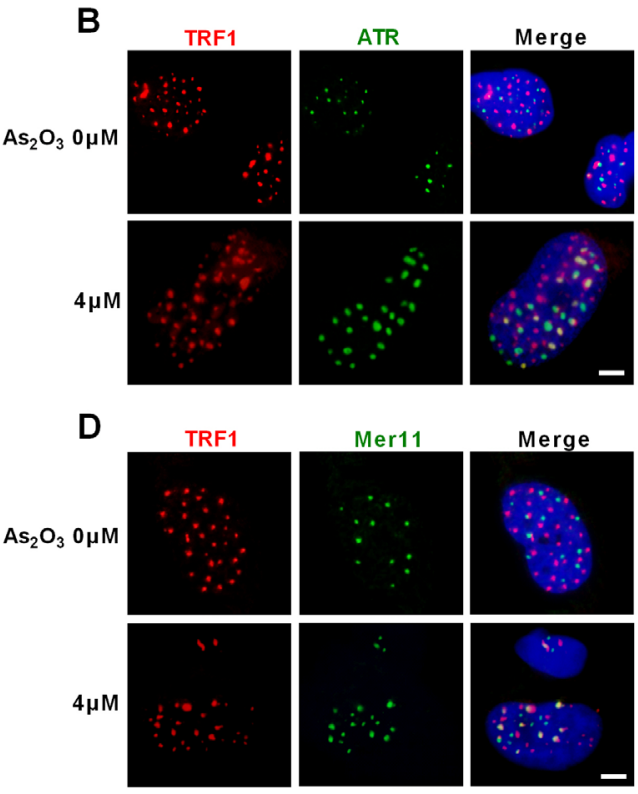

E

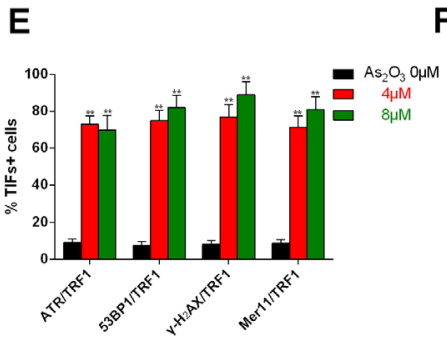

$\mathbf{F}$
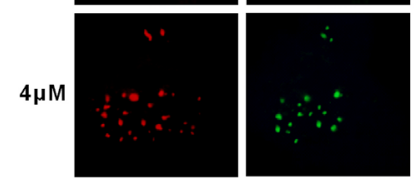

G
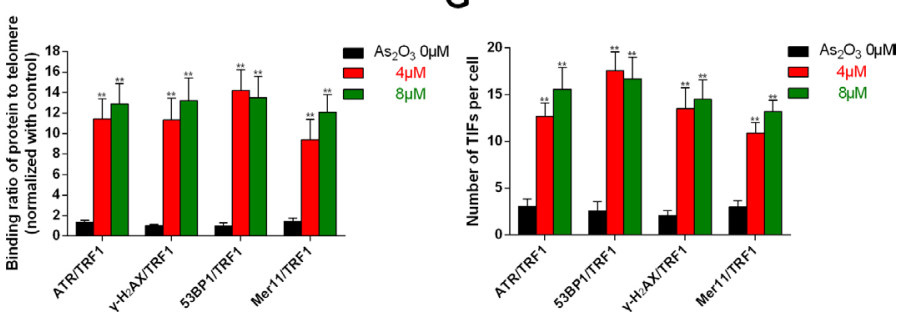

Figure 4: DNA-damage response triggered by $\mathrm{As}_{2} \mathrm{O}_{3}$ occurred at telomeres. A-D. $\mathrm{As}_{2} \mathrm{O}_{3}$-treated U87 cells were double stained with the indicated antibodies. Representative confocal images showing merged TRF1 (red) with ATR, 53BP1, $\gamma-\mathrm{H}_{2} \mathrm{AX}$ or Mer11 (green) staining in untreated and $\mathrm{As}_{2} \mathrm{O}_{3}$-treated cells. Scale bar $=5 \mu \mathrm{m}$. E. TIF indexes, defined as foci of DNA-damage response factors that coincide with TRF1, were calculated as the percentage of TIF-positive cells among glioma cells treated with $\mathrm{As}_{2} \mathrm{O}_{3}$. Cells with four or more co-localization foci were scored as TIF-positive. The mean of three independent experiments was reported. Error bars indicate s.d. $* * \mathrm{P}$ $<0.001$, two-tailed Student's $t$-test. F. Average number of TIFs per nucleus in $\mathrm{As}_{2} \mathrm{O}_{3}$-treated glioma cells. The mean of three independent experiments with comparable results is shown. Error bars indicate \pm s.d. $* * \mathrm{P}<0.005$, two-tailed Student's $t$-test. G. Chip assays showed the effect of $4 \mu \mathrm{m} \mathrm{As} \mathrm{O}_{3}$ on binding of ATR, $\gamma-\mathrm{H}_{2} \mathrm{AX}, 53 \mathrm{BP} 1$ or Mer11 to telomeres. Data depict triplicate ChIP experiments, each with technical triplicates of qRT-PCR; **P $<0.01$ as compared to control. 
$\gamma-\mathrm{H}_{2} \mathrm{AX}$ and Mer11 were situated on TRF1, which means the site of the DNA damage is the telomere. Previous reports indicate that arsenic has the ability to bind to the telomere at a specific binding site [41]. Our findings are consistent with that earlier result. It was also previously observed that increased ROS generation is the main reason for $\mathrm{As}_{2} \mathrm{O}_{3}$-induced DNA damage [42]. Consistent with that finding, we observed that $\mathrm{As}_{2} \mathrm{O}_{3}$ dose-dependently induced ROS generation, which led to dose-dependent increases in the expression of DNA damage proteins.

There are two primary responses after DNA double-strand breaks: DNA repair or cell cycle arrest and apoptosis. In our study, the up-regulation of p53 and phospho-p53 indicated the failure of DNA repair and start a p53-dependent apoptosis, which is in agreement with Gazitt's study [43]. The up-regulation of Bax, an apoptosis-promoting protein, was induced by $\mathrm{p} 53$, which is additional evidence of p53-dependent apoptosis [44]. Cell cycle arrest is another result of DNA damage [45]. ATM and ATR are major signals of G2-M phase arrest resulting from DNA damage [46]. The phosphorylation of PI3k and p53 by ATM induces the cell cycle block [47, 48]. The phosphorylation/activation of $\mathrm{p} 53$ induces $\mathrm{G} 2 / \mathrm{M}$ arrest primarily by disrupting the function of the cyclin B1/cdc2 complex. Specifically, p53 represses cdc25c, a phosphatase that promotes mitosis, after DNA damage [49]. Our finding that cyclin B1 is down-regulated in $\mathrm{As}_{2} \mathrm{O}_{3}$-treated cells is in agreement with those earlier results. By contrast, our finding that cyclin D1 remained unchanged after $\mathrm{As}_{2} \mathrm{O}_{3}$ treatment indicates the absence of obstruction in the transition of G1-S.
A

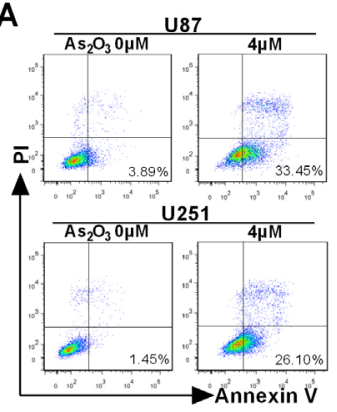

D

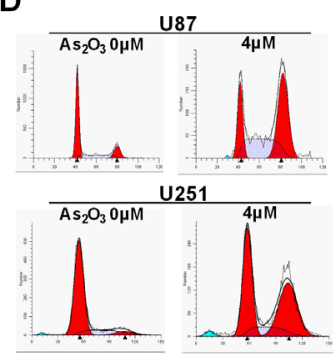

B

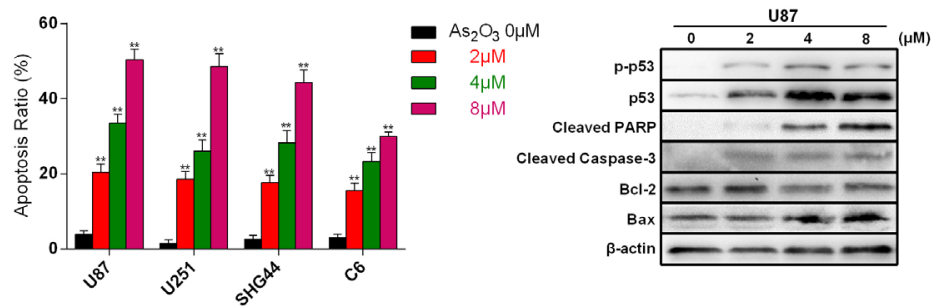

E

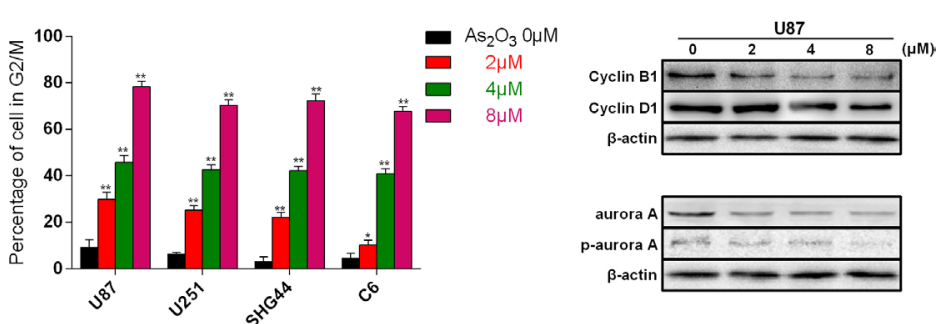

$\mathrm{H}$
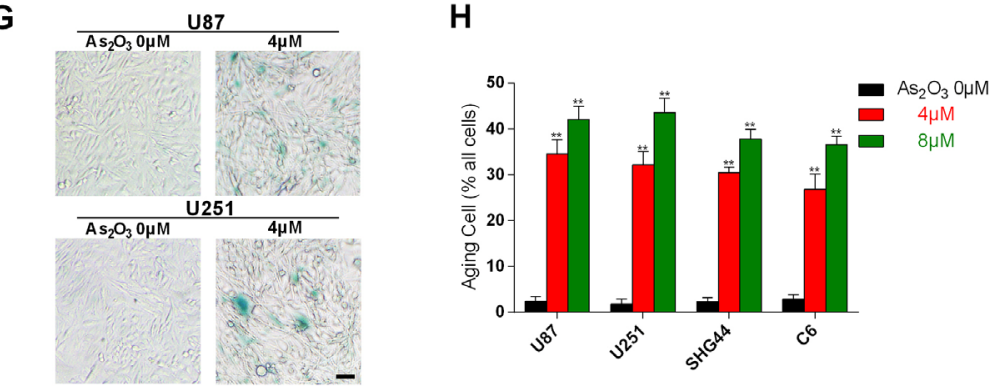

Figure 5: Cell apoptosis, cell cycle arrest and cellular senescence evoked by $\mathrm{As}_{2} \mathrm{O}_{3}$-induced telomere dysfunction. A. Flow cytometric analysis of $\mathrm{As}_{2} \mathrm{O}_{3}$-induced apoptotic cell death revealed by staining with PI and Annexin V-FITC. B. Dose-dependence of $\mathrm{As}_{2} \mathrm{O}_{3}$-induced apoptosis in U87, U251, SHG4 and C6 cells. This experiment was repeated three times. ${ }^{* *} \mathrm{P}<0.001$. C. Immunoblots showing the expression levels of apoptosis-related proteins. Note the dose-dependent up-regulation of p53, p-p53, Bax, cleaved PARP and cleaved Caspase-3 and down-regulation of Bcl-2 in $\mathrm{As}_{2} \mathrm{O}_{3}$-treated cells. D. Representative $\mathrm{As}_{2} \mathrm{O}_{3}$-induced cell cycle arrest. Cells were collected and stained with PI; DNA content was determined by flow cytometry. The percentages of cells undergoing apoptosis (sub-G1\%) are expressed with respect to the total number of cells. E. Dose-dependent $\mathrm{As}_{2} \mathrm{O}_{3}$-induced $\mathrm{G}_{2} / \mathrm{M}$ arrest in U87, U251, SHG4 and C6 cells. This experiment was repeated three times. ${ }^{*} \mathrm{P}<0.05$, ${ }^{*} * \mathrm{P}<0.01$. F. Immunoblots showing the expression levels of cell cycle-related proteins. G) Representative photomicrographs showing cellular senescence induced by exposure to $\mathrm{As}_{2} \mathrm{O}_{3}$ for 2 weeks. The cells are stained with $\beta$-galactosidase (SA- $\beta$-gal) stain. H. Dose-dependent increases in the incidence of $\mathrm{As}_{2} \mathrm{O}_{3}$-induced cellular senescence in U87, U251, SHG4 and C6 cells. This experiment was repeated three times. ${ }^{* *} \mathrm{P}<0.001$. 
Finally, we found that $\mathrm{As}_{2} \mathrm{O}_{3}$ induces a significant dose-related increase in the incidence of cellular senescence. Many factors contribute to the induction of cellular senescence, including telomerase suppression, telomere damage and chromosomal damage, though the main factor is telomere dysfunction [50]. The significant elevations of p53 and p 21 that we observed are consistent with cellular senescence. p21 is usually suppressed in malignant cells. The resultant p21 deficiency enables escape from senescence through chromosome doubling, high DNA replication and improved repair potential. In addition, p21 deficiency also decreases the DNA damage checkpoint response (DDR), which is another possible route enabling escape from senescence. $\mathrm{As}_{2} \mathrm{O}_{3}$-induced telomere dysfunction results in p53- and p21-mediated cell apoptosis, G2/M cell cycle arrest and senescence.

In sum, our observations provide new insight into the antitumor effects of $\mathrm{As}_{2} \mathrm{O}_{3}$, which appears to act by interfering with telomerase activity and telomere function, and can perhaps contribute to solving the problem of glioblastoma treatment resistance.

\section{MATERIALS AND METHODS}

\section{Cell culture and treatment}

U87 (human glioblastoma), U251 (human glioblastoma), SHG-44 (human glioma) and C6 (rat glioma) cell lines were obtained from the American Type Culture Collection (ATCC). Rat glioma C6 cells are widely used for in vitro experiments. Although they are less malignant than human glioblastoma cells, $\mathrm{C} 6$ cells were used as a model to better explain the effect of $\mathrm{A}_{\mathrm{s} 2} \mathrm{O}_{3}$ on glioblastoma. The cells were grown in Dulbecco's modified eagle medium (DMEM) supplemented with 10\% fetal bovine serum (FBS) (Biowest, South America Origin) in a humidified incubator maintained at $37{ }^{\circ} \mathrm{C}$ with $95 \%$ air and $5 \% \mathrm{CO}_{2} . \mathrm{As}_{2} \mathrm{O}_{3}$ (solid state) was purchased from Sigma Chemical Co. (St. Louis, Missouri, USA). After preparing a $5 \mathrm{mM}$ stock solution in phosphate buffered saline (PBS), the solution was filtered and stored at $-80^{\circ} \mathrm{C}$. The frozen $\mathrm{As}_{2} \mathrm{O}_{3}$ solution is stable for over 6 months. Working concentrations were freshly prepared daily by diluting the stock with serumfree DMEM.

\section{Cell proliferation assays}

The cytotoxicity of $\mathrm{As}_{2} \mathrm{O}_{3}$ toward glioma cells was assessed using MTT assays. Cells in the log growth phase were seeded onto 96-well microplates at a density of $5 \times 10^{3}$ cells in $200 \mu \mathrm{l}$ of medium per well and left to attach overnight prior to treatment. $\mathrm{As}_{2} \mathrm{O}_{3}$ was then added to various final concentrations. Dimethyl sulphoxide (DMSO) vehicle served as a control. Twenty microliters of MTT solution ( $5 \mathrm{mg} / \mathrm{ml}$; Sigma Aldrich, USA) were added $4 \mathrm{~h}$ before the end of the incubation period, and the reaction was terminated by adding $10 \%$ acidified sodium dodecyl sulfate. Formazan crystals in the cells were dissolved in DMSO, after which the absorbance at $570 \mathrm{~nm}$ was measured using a microplate reader (Bio-Tek Instruments, USA).

\section{Invasion and migration assays}

Twenty-four-well plates with BioCoat Invasion Chambers (BD) were used to test the invasion or migration of glioma cells. Each chamber contained an 8 - $\mu \mathrm{m}$-pore polycarbonate transwell membrane, with or without Matrigel coating. Cells $\left(2 \times 10^{5} / \mathrm{ml}\right)$ were resuspended in $200 \mu \mathrm{l}$ of serum-free medium and plated on the top side of the membrane without Matrigel for migration assays or with Matrigel for transwell matrix penetration assays. The cells were then incubated at $37^{\circ} \mathrm{C}$ for $48 \mathrm{~h}$, followed by removal of the cells from the upper chamber with cotton swabs. The migrated and invaded cells on the lower membrane surface were fixed in $4 \%$ formaldehyde and stained with $0.1 \%$ of crystal violet for $5 \mathrm{~min}$. Five fields of cells were counted randomly in each well under a microscope at $200 \mathrm{x}$ magnification.

\section{Flow cytometric assays}

Glioma cells were plated at $10^{5}$ cells per well in sixwell plates and allowed to adhere for $12 \mathrm{~h}$ at $37^{\circ} \mathrm{C}$ before exposure to $\mathrm{As}_{2} \mathrm{O}_{3}$ solution $(0,2,4$ or $8 \mu \mathrm{M})$ for $48 \mathrm{~h}$. To detect cell cycle, collected cells were incubated in $70 \%$ ethanol for $12 \mathrm{~h}$ at $-20^{\circ} \mathrm{C}$, washed twice with PBS, and incubated with $1 \mathrm{~g} / \mathrm{mL}$ propidium iodide (PI) and RNase for $25 \mathrm{~min}$. Cell apoptosis was detected using an FITC Annexin V Apoptosis Detection Kit (BD Pharmingen, Inc.). Cells were incubated first in the $1 \times$ binding buffer, then for 15 min with PI and FITC Annexin V in binding buffer while shaking. Reactive oxygen species (ROS) were detected using a ROS detection Kit (ZSGB-BIO). The cells were incubated for $30 \mathrm{~min}$ in pre-warmed $\left(37^{\circ} \mathrm{C}\right)$ PBS containing $1 \mu \mathrm{M}$ CM-H2DCFDA (Molecular Probes, Eugene, OR, USA). The loading buffer was then removed, and the cells were returned to growth medium containing $\mathrm{As}_{2} \mathrm{O}_{3}(0,2,4,8$ or $16 \mu \mathrm{M})$.

\section{Telomeric repeat amplification protocol assay}

Telomerase enzyme activity was measured using a TRAP assay with cell extracts exposed to $\mathrm{As}_{2} \mathrm{O}_{3}$ for $48 \mathrm{~h}$ in situ at concentrations of $0,2,4,8$ or $16 \mu \mathrm{M}$. TRAP assay was performed as previously reported [51]. A TRAPeze kit (Roche Diagnostics) was used to measure the effects of $\mathrm{As}_{2} \mathrm{O}_{3}$ on U87, U251, SHG44 and $\mathrm{C} 6$ cell lysates. Total cellular protein $(2 \mu \mathrm{g})$ was used for each PCR. The PCR products were separated on a PAGE gel. 


\section{Cell senescence staining}

Glioma cells were plated at $5 \times 10^{4}$ cells per well in 6-well plates and exposed to $\mathrm{As}_{2} \mathrm{O}_{3}$ at a concentration of $0,2,4$ or $8 \mu \mathrm{M}$ for 2 weeks (the cells were collected for passage on day 7). They were stained with a solution of citric acid, X-gal and ferric iron. Fixed Buffer was used for fixation for $1 \mathrm{~h}$, after which the cells were immersed in cold PBS for observation. Finally, an inverted microscope (Olympus, Japan) was used for photographing.

\section{Immunoblotting}

Immunoblotting was performed as previously reported [51]. Total proteins were extracted from the cultured cells. Samples containing 30-35 $\mu \mathrm{g}$ of total protein were subjected to $8-12 \%$ SDS polyacrylamide gel electrophoresis (PAGE), transferred onto a nitrocellulose membrane (Roche), and probed with following monoclonal primary antibodies: anti-actin (SigmaAldrich, Inc.), anti-TRF1, anti-hTERT, anti-hTERT ${ }^{\text {Tyr707, }}$ anti- $\gamma-\mathrm{H}_{2} \mathrm{AX}$, anti-53BP1, anti-ATM, anti-p-ATM, antiATR, anti-Mer11, anti-Bcl-2, anti-Cyclin B1, anti-Cyclin D1, anti-aurora A, anti-p-aurora A, anti-p53 and anti-p21 (Santa Cruz Biotechnology, Inc.). HRP-conjugated goat anti-rabbit and goat anti-mouse antibody (ZSGB-BIO) were then used as secondary antibodies.

\section{Immunofluorescence}

Immunofluorescence was performed as previously reported [51]. Cells were fixed in $2 \%$ formaldehyde and permeabilized in $0.25 \%$ Triton X100 in PBS for 5 min at room temperature. For immunolabeling, cells were incubated with primary antibody, washed in PBS and incubated with fluorophore-conjugated secondary antibodies. The following monoclonal primary antibodies were used: anti-TRF1, anti-ATR, anti- $\gamma-\mathrm{H}_{2} \mathrm{AX}$, anti53BP1, anti-Mer11 and anti-hTERT, (Santa Cruz Biotechnology, Inc.). Rhodamine- or DyLightTM488conjugated goat anti-rabbit and fluorescein- or DyLightTM594-conjugated goat anti-mouse (ZSGB-BIO) served as secondary antibodies. Fluorescence signals were captured using an Olympus Fluoview FV1000 confocal microscope and analyzed using the FV10-ASW 1.6 Viewer program (Olympus, Japan).

\section{ChIP assays}

ChIP assays were performed as previously reported [51] and according to manufacturer's instructions (Millipore). Briefly, cells were fixed in $0.8 \%$ paraformaldehyde in $1 \times \mathrm{PBS}$, washed extensively in $1 \times$ PBS, and lysed in ice-cold lysis buffer $(1 \%$ SDS, 10 $\mathrm{mM}$ EDTA, $50 \mathrm{mM}$ Tris- $\mathrm{HCl}$ and protease inhibitors at $\mathrm{pH}$ $8.0)$. The chromatin products were the sonicated $(\sim 100$ $300 \mathrm{bp})$ and diluted $10 \times$ in dilution buffer $(20 \mathrm{mM}$ Tris-
$\mathrm{HCl}, 150 \mathrm{mM} \mathrm{NaCl}, 2 \mathrm{mM}$ EDTA, protease inhibitors and $1 \mathrm{mg} / \mathrm{ml} \mathrm{BSA}$ at $\mathrm{pH} 8.0$ ). ChIP was performed using the relevant antibody and captured with Protein A/GSepharose. DNA-protein complexes were washed with $1 \times$ wash buffer I $(20 \mathrm{mM}$ Tris- $\mathrm{HCl}, 150 \mathrm{mM} \mathrm{NaCl}, 0.1 \%$ SDS, $1 \%$ Triton X-100 and $2 \mathrm{mM}$ EDTA at $\mathrm{pH} 8.0$ ), $2 \times$ wash buffer II $(20 \mathrm{mM}$ Tris- $\mathrm{HCl}, 250 \mathrm{mM} \mathrm{NaCl}, 0.1 \%$ SDS, $1 \%$ Triton X-100 and 2 mM EDTA at $\mathrm{pH} 8.0$ ) and eluted in $1 \% \mathrm{SDS}$ and $100 \mathrm{mM} \mathrm{NaHCO}_{3}$. Eluate fractions were de-crosslinked in high-salt solution $(200 \mathrm{mM} \mathrm{NaCl})$ at $60^{\circ} \mathrm{C}$ followed by proteinase $\mathrm{K}$ treatment at $50^{\circ} \mathrm{C}$. Extracted DNA was subjected to PCR as previously reported [51].

\section{Statistics}

Statistical significance between two treatment groups was evaluated using the Student's $t$ test; $\mathrm{P}<0.05$ was considered significant. SAS version 9.2 (SAS Institute Inc., Cary, North Carolina) and Excel 2013 (Microsoft Corp., Redmond, WA) were used for all statistical analyses.

\section{CONFLICTS OF INTEREST}

All authors declare no conflicts of interest

\section{REFERENCES}

1. Stupp R, Mason WP, van den Bent MJ, Weller M, Fisher B, Taphoorn MJ, Belanger K, Brandes AA, Marosi C, Bogdahn U, Curschmann J, Janzer RC, Ludwin SK, et al. Radiotherapy plus concomitant and adjuvant temozolomide for glioblastoma. N Engl J Med. 2005; 352: 987-996.

2. Stupp R, Hegi ME, Mason WP, van den Bent MJ, Taphoorn MJ, Janzer RC, Ludwin SK, Allgeier A, Fisher B, Belanger K, Hau P, Brandes AA, Gijtenbeek J, et al. Effects of radiotherapy with concomitant and adjuvant temozolomide versus radiotherapy alone on survival in glioblastoma in a randomised phase III study: 5-year analysis of the EORTCNCIC trial. Lancet Oncol. 2009; 10: 459-466.

3. Kanzawa T, Kondo Y, Ito H, Kondo S, Germano I. Induction of autophagic cell death in malignant glioma cells by arsenic trioxide. Cancer Res. 2003; 63: 2103-2108.

4. Murgo AJ. Clinical trials of arsenic trioxide in hematologic and solid tumors: overview of the National Cancer Institute Cooperative Research and Development Studies. Oncologist 2001; 6 Suppl 2: 22-28.

5. Chen GQ, Shi XG, Tang W, Xiong SM, Zhu J, Cai X, Han ZG, Ni JH, Shi GY, Jia PM, Liu MM, He KL, Niu C, et al. Use of arsenic trioxide $\left(\mathrm{As}_{2} \mathrm{O}_{3}\right)$ in the treatment of acute promyelocytic leukemia (APL): I. $\mathrm{As}_{2} \mathrm{O}_{3}$ exerts dose-dependent dual effects on APL cells. Blood 1997; 89: 3345-3353.

6. Shen ZX, Chen GQ, Ni JH, Li XS, Xiong SM, Qiu QY, Zhu J, Tang W, Sun GL, Yang KQ, Chen Y, Zhou L, Fang ZW, 
et al. Use of Arsenic Trioxide $\left(\mathrm{As}_{2} \mathrm{O}_{3}\right)$ in the Treatment of Acute Promyelocytic Leukemia (APL): II. Clinical Efficacy and Pharmacokinetics in Relapsed Patients. Blood 1997; 89: 3354-3360.

7. Jiang TT, Brown SL, Kim JH. Combined effect of arsenic trioxide and sulindac sulfide in A549 human lung cancer cells in vitro. J Exp Clin Cancer Res. 2004; 23: 259-262.

8. Chow SK, Chan JY, Fung KP. Inhibition of cell proliferation and the action mechanisms of arsenic trioxide $\left(\mathrm{As}_{2} \mathrm{O}_{3}\right)$ on human breast cancer cells. J Cell Biochem 2004; 93: 173-187.

9. Rust DM, Soignet SL. Risk/benefit profile of arsenic trioxide. Oncologist 2001; 6 Suppl 2:29-32.

10. Yih LH, Tseng YY, Wu YC, Lee TC. Induction of centrosome amplification during arsenite-induced mitotic arrest in CGL-2 cells. Cancer Res 2006; 66: 2098-2106.

11. Phatak P, Dai F, Butler M, Nandakumar MP, Gutierrez PL, Edelman MJ, Hendriks H, Burger AM. KML001 cytotoxic activity is associated with its binding to telomeric sequences and telomere erosion in prostate cancer cells. Clin Cancer Res 2008; 14: 4593-4602.

12. de Lange, T. How telomeres solve the end-protection problem. Science. 2009; 326: 593-597.

13. van Steensel B, Smogorzewska A, de Lange T. TRF2 protects human telomeres from end-to-end fusions. Cell. 1998; 92: 401-413.

14. Jiao Y, Zhang W, Liu J, Ni W, Xu W, Jin J, Qian W. Telomere attrition and chromosome instability via downregulation of TRF2 contributes to arsenic trioxide-induced apoptosis of human T-Cell leukemia cell line molt-4 cells. Cancer Biol Ther 2007; 6: 1186-1192.

15. Dorris K, Sobo M, Onar-Thomas A, Panditharatna E, Stevenson CB, Gardner SL, Dewire MD, Pierson CR, Olshefski R, Rempel SA, Goldman S, Miles L, Fouladi $\mathrm{M}$, et al. Prognostic significance of telomere maintenance mechanisms in pediatric high-grade gliomas. J Neurooncol. 2014; 117: 67-76.

16. Wu J, Ji Z, Liu H, Liu Y, Han D, Shi C, Shi C, Wang C, Yang G, Chen X, Shen C, Li H, Bi Y, et al. Arsenic trioxide depletes cancer stem-like cells and inhibits repopulation of neurosphere derived from glioblastoma by downregulation of Notch pathway. Toxicol Lett. 2003; 220: 61-69.

17. Wang C, Chen X, Zou H, Chen X, Liu Y, Zhao S. The roles of mitoferrin-2 in the process of arsenic trioxide-induced cell damage in human gliomas. Eur J Med Res. 2014; 19: 49.

18. Fan K, Uzman BG. Rat glioma cells (C6) cultured in serumfree defined medium. Exp Cell Res 1977; 106: 397-401.

19. Tahara H, Kusunoki M, Yamanaka Y, Matsumura S, Ide T. G-tail telomere HPA: simple measurement of human single-stranded telomeric overhangs. Nat. Methods 2005; 2: 829-831.

20. Takai H, Smogorzewska A, de Lange T. DNA damage foci at dysfunctional telomeres. Curr. Biol 2003; 13: 1549-1556.
21. Kim YJ, Chung JY, Lee SG, Kim JY, Park JE, Kim WR, Joo BS, Han SH, Yoo KS, Yoo YH, Kim JM. Arsenic trioxide-induced apoptosis in TM4 Sertoli cells: the potential involvement of p21 expression and p53 phosphorylation. Toxicology. 2011; 285: 142-151.

22. Qian W, Liu J, Jin J, Ni W, Xu W. Arsenic trioxide induces not only apoptosis but also autophagic cell death in leukemia cell lines via upregulation of Beclin-1. Leukemia Res. 2007; 31: 329-339.

23. Li CL, Wei HL, Chen J, Wang B, Xie B, Fan LL, Li LJ. Arsenic trioxide induces autophagy and antitumor effects in Burkitt's lymphoma Raji cells. Oncol Rep. 2014; 32: 1557-1563.

24. Evans T, Rosenthal ET, Youngblom J, Distel D, Hunt T. Cyclin: a protein specified by maternal mRNA in sea urchin eggs that is destroyed at each cleavage division. Cell 1983; 33: 389-396.

25. Lee SY, Lee GR, Woo DH, Park NH, Cha HJ, Moon YH, Han IS. Depletion of Aurora A leads to upregulation of FoxO1 to induce cell cycle arrest in hepatocellular carcinoma cells. Cell Cycle. 2013; 12: 67-75.

26. Finley RL Jr, Thomas BJ, Zipursky SL, Brent R. Isolation of Drosophila Cyclin D, a protein expressed in the morphogenetic furrow before entry into S phase. Proc Natl Acad Sci. 1996; 93: 3011-3015.

27. Blackburn E, Greider C, Szostak J. Telomeres and telomerase: the path from maize, Tetrahymena and yeast to human cancer and aging. Nat Med 2006; 12: 1133-1138.

28. Palm W, de Lange T. How shelterin protects mammalian telomeres. Annu Rev Genet. 2008; 42:301-334.

29. Shay JW, Keith WN. Targeting telomerase for cancer therapeutics. Br J Cancer 2008. 98: 677-683.

30. Cunningham D, Atkin W, Lenz HJ, Lynch HT, Minsky B, Nordlinger B. Starling N. Colorectal cancer. Lancet. 2010; 375: 1030-1047.

31. Ruden M, Puri N. Novel anticancer therapeutics targeting telomerase. Cancer Treat Rev. 2013; 39: 444-456.

32. Moro-García MA, Alonso-Arias R, López-Larrea C. Molecular mechanisms involved in the aging of the T-cell immune response, Curr. Genomics. 2012; 13: 589-602.

33. Rufer N, Dragowska W, Thornbury G, Roosnek E, Lansdorp PM. Telomere length dynamics in human lymphocyte subpopulations measured by flow cytometry. Nat Biotechnol. 1998; 16: 743-747.

34. Haendeler J, Hoffmann J, Diehl JF, Vasa M, Spyridopoulos I, Zeiher AM, Dimmeler S. Antioxidants inhibit nuclear export of telomerase reverse transcriptase and delay replicative senescence of endothelial cells. Circ Res. 2004; 94 : 768-775.

35. Monteiro J, Batliwalla F, Ostrer H, Gregersen PK. Shortened telomeres in clonally expanded CD28-CD8+ $\mathrm{T}$ cells imply a replicative history that is distinct from 
their CD28+CD8+ counterparts. J Immunol. 1996; 156: 3587-3590.

36. Vogel EW, Natarajan AT. DNA damage and repair in somatic and germ cells in vivo. Mutat Res. 1995; 330: 183-208.

37. Luo Q, Li Y, Deng J, Zhang Z. PARP-1 inhibitor sensitizes arsenic trioxide in hepatocellular carcinoma cells via abrogation of G2/M checkpoint and suppression of DNA damage repair. Chem Biol Interact. 2015; 226: 12-22.

38. Kryeziu K, Jungwirth U, Hoda MA, Ferk F, Knasmüller S, Karnthaler-Benbakka C, Kowol CR, Berger W, Heffeter P. Synergistic anticancer activity of arsenic trioxide with erlotinib is based on inhibition of EGFR-mediated DNA double-strand break repair. Mol Cancer Ther. 2013; 12: 1073-1084.

39. Cooper TJ, Wardell K, Garcia V, Neale MJ. Homeostatic regulation of meiotic DSB formation by ATM/ATR. Exp Cell Res. 2014; 329: 124-131.

40. Khanna KK, Keating KE, Kozlov S, Scott S, Gatei M, Hobson K, Taya Y, Gabrielli B, Chan D, Lees-Miller SP, Lavin MF. ATM associated with and phosphorylate p53: mapping the region of interaction. Nat Genet. 1998; 20: 398-400.

41. Alarifi S, Ali D, Alkahtani S, Siddiqui MA, Ali BA. Arsenic trioxide-mediated oxidative stress and genotoxicity in human hepatocellular carcinoma cells. Onco Targets Ther. 2013; 6: 75-84.

42. Haga N, Fujita N, Tsuruo T. Involvement of mitochondrial aggregation in arsenic trioxide $\left(\mathrm{As}_{2} \mathrm{O}_{3}\right)$-induced apoptosis in human glioblastoma cells. Cancer Sci. 2005; 96: 825-833.
43. Gazitt Y, Akay C. Arsenic trioxide: an anticancer missile with multiple warheads. Hematology. 2005; 10: 205-213.

44. Agarwal ML, Taylor WR, Chernov MV, Chernova OB, Stark GR. The p53 network. J Biol Chem. 1998; 273:1-4.

45. Schiestl RH, Reynolds P, Prakash S, Prakash L. Cloning and sequence analysis of the Saccharomyces cerevisiae RAD9 gene and further evidence that its product is required for cell cycle arrest induced by DNA damage. Mol Cell Biol. 1989; 9: 1882-1896.

46. Morii M, Fukumoto Y, Kubota S, Yamaguchi N, Nakayama Y, Yamaguchi N. Imatinib inhibits inactivation of the ATM/ATR signaling pathway and recovery from adriamycin/doxorubicin-induced DNA damage checkpoint arrest. Cell Biol Int. 2015; 19.

47. Agami R, Bernards R. Distinct initiation and maintenance mechanisms cooperate to induce G1 cell cycle arrest in response to DNA damage. Cell. 2000; 102: 55-66.

48. Fitzgerald ML, Moore KJ, Freeman MW, Reed GL. Lipopolysaccharide induces scavenger receptor A expression in mouse macrophages: a divergent response relative to human THP-1 monocyte/macrophages. J Immunol. 2000; 164: 2692-2700.

49. Zilfou JT, Lowe SW. Tumor suppressive functions of p53. Cold Spring Harb Perspect Biol. 2009; 1: a001883.

50. Weiss CN, Ito K. DNA Damage: A Sensible Mediator of the Differentiation Decision in Hematopoietic Stem Cells and in Leukemia. Int J Mol Sci. 2015; 16: 6183-6201.

51. Chen Y, Qu K, Zhao C, Wu L, Ren J, Wang J, Qu X. Insights into the biomedical effects of carboxylated singlewall carbon nanotubes on telomerase and telomeres. Nat Commun. 2012; 3:1074. 